\title{
Exogenous Antioxidants Enhance Seedling Growth and Yield of Artificially Aged Cabbage and Lettuce Seeds
}

\author{
Ademola Emmanuel Adetunji ${ }^{1, *(D)}$, Sershen ${ }^{2,3}$, Boby Varghese ${ }^{1}$ and Norman W. Pammenter ${ }^{1}$ \\ 1 School of Life Sciences, University of KwaZulu-Natal, Durban 4001, South Africa; varghese@ukzn.ac.za (B.V.); \\ pammente@ukzn.ac.za (N.W.P.) \\ 2 Department for Biodiversity and Conservation Biology, University of the Western Cape, \\ Private Bag X17, Bellville 7535, South Africa; sershenn@gmail.com \\ 3 Institute of Natural Resources, P.O. Box 100396, Scottsville 3209, South Africa \\ * Correspondence: adetunjiademola@hotmail.com
}

check for

updates

Citation: Adetunji, A.E.; S.; Varghese, B.; Pammenter, N.W. Exogenous Antioxidants Enhance Seedling Growth and Yield of Artificially Aged Cabbage and Lettuce Seeds. Horticulturae 2021, 7, 274. https://doi.org/10.3390/ horticulturae7090274

Academic Editor: Sergio Ruffo Roberto

Received: 9 August 2021

Accepted: 28 August 2021

Published: 1 September 2021

Publisher's Note: MDPI stays neutral with regard to jurisdictional claims in published maps and institutional affiliations.

Copyright: (c) 2021 by the authors. Licensee MDPI, Basel, Switzerland. This article is an open access article distributed under the terms and conditions of the Creative Commons Attribution (CC BY) license (https:// creativecommons.org/licenses/by/ $4.0 /)$.
Abstract: Aged seeds exhibit compromised vigour in terms of germination, seedling emergence and growth, but this can to some extent be alleviated by invigoration treatments before sowing. This study aimed to investigate ageing rates and patterns in cabbage (Brassica oleraceae) and lettuce (Lactuca sativa) seeds and whether the beneficial effects of invigorating aged seeds with exogenous antioxidants translate to enhanced seedling performance. Seeds were artificially aged to $25 \%$ viability before soaking in $0.4 \mathrm{mM}$ glycerol, $0.6 \mathrm{mM}$ GSH and $0.2 \mathrm{mM}$ trolox for cabbage, and $0.6 \mathrm{mM}$ glycerol, GSH and trolox for lettuce; deionised water served as a control. After 14 days of sowing, seedling emergence percentage, mean emergence time, mean daily emergence, and time taken to $25 \%$ emergence were computed. Seedling vigour index, root and shoot dry weight, root:shoot ratio, leaf area, leaf area ratio, and leaf chlorophyll content were assessed 6 weeks after sowing. Furthermore, the photosynthetic rate (Pn), stomatal conductance (Gs), transpiration rate (E), and chlorophyll fluorescence were measured 6 weeks after sowing. Notably, ageing resulted in the loss of seed vigour and viability at higher rates in lettuce than cabbage. Seed pretreatment with glycerol promoted seedling growth in both species and shoot dry weight in lettuce, while glycerol and GSH enhanced Pn, Gs and E in lettuce. Trolox also enhanced Pn and E in lettuce. The beneficial effects of the antioxidant treatments are thought to be associated with the protection of photosystems from oxidative stress and/or stimulation of enzymes involved in photosynthesis, possibly through an enhanced antioxidant defence system during the early development stages when seedlings are particularly vulnerable to stress.

Keywords: ageing rate and pattern; glycerol; invigoration; photosynthesis; seedling growth

\section{Introduction}

Seeds are continually faced with multiple challenges relating to production, postharvest storage, and subsequent quality. Moreover, in view of the effects of global warming as a symptom of climate change, different stress factors may cause poor seed performance in terms of reduced germination, uneven seedling emergence, poor seedling establishment, destructive alteration of root cell architecture, and thereby leading to a substantial yield loss [1]. Standard germination assessments can be used to predict the actual field performance of seeds [2], but the predictions of subsequent establishment and growth are not entirely reliable [3]. Good field performance, especially in agricultural seeds, requires good emergence and establishment of seedlings for maximal yield. Studies have indicated differences in seed performance under optimal laboratory conditions compared with field conditions, which are rarely optimal. Emergence success in the field is often substantially lower than the germination success measured in the laboratory [4,5], especially when soil conditions become less favourable [6-8]. Seedling emergence percentage, emergence rate, and shoot fresh and dry biomass have been reported to be higher in pre-hydrated caraway 
(Carum carvi) seeds sown in the soil as opposed to Petri dishes [9]. Similarly, a massive difference between viability estimated by tetrazolium staining and laboratory germination techniques and soil establishment was discernible in 39 strains and cultivars of common bean (Phaseolus vulgaris) seeds [10]. Lubbe et al [11] reported that the germination capacity of spleen amaranth (Amaranthus dubius) seeds treated with greywater in Petri dishes was rather enhanced than when seeds treated in the same way were sown in the soil. Such disparity in germination and seedling establishment is critical as it has an impact on crop productivity. Situations may become more precarious when seeds that have been kept for long in seed banks are sown. Poor field performance has been reported in aged seeds of several species. In a seed ageing test, using an International Seed Testing Association (ISTA, 1985) validated and frequently employed method of assessing the vigour and quality of seed, the performance of soybean seeds (Glycine max) subjected to accelerated ageing varied markedly from field responses [2].

Seed ageing is a consequence of the production and accumulation of reactive oxygen species (ROS), which are toxic oxidants that bring about physical and biochemical lesions [12-15]. The ROS attack major biomolecules such as proteins, nucleic acids, and lipids during oxidative stress, resulting in physiological injuries like the loss of membrane integrity, degradation and inactivation of enzymes and reduced respiration [16,17], thereby affecting seed quality, vigour and early seedling growth [15,17-19]. Given that seed ageing occurs over extremely protracted periods in many domesticated species, several studies have employed controlled deterioration (CD) to investigate the ageing phenomenon. These studies collectively showed that even when factors such as moisture level and temperature are controlled for, the rate of vigour and viability loss varies across species [17,20-22]. This variation is a function of the ability of seeds of different species to resist degradative changes through protective mechanisms to varying degrees [22].

In attempts to alleviate poor seed performance due to ageing, a few studies have recommended the exogenous application of antioxidants such as ascorbic acid [23], trolox (as tocopherol) [24], and glutathione [25] to neutralise the harmful oxidants capable of causing seed deterioration in various species. Even the known radioprotectant, glycerol [26,27], has been suggested to scavenge and/or reduce the formation of harmful oxidants in seed embryonic axes exposed to stress [28]. It is also known to maintain cellular stability under abiotic stress $[28,29]$. Such treatments were reported to enhance seedling emergence percentage, speed of emergence, vigour, biomass accumulation, and leaf photosynthetic efficiency in sunflower (Helianthus annuus) seeds [24] and wheat (Triticum aestivum) [30,31]. Other promotive effects, including increased starch hydrolysing enzyme ( $\alpha$-amylase) activity, high soluble sugars levels, allometry, and increased seed yield, have been reported in field studies of rice (Oryza sativa) grains treated with ascorbic acid [32]. Improved morphological attributes and grain yield of temperature-stressed maize (Zea mays) seeds treated with exogenously applied ascorbic acid, and salicylic acid, and hydrogen peroxide (signalling molecules that can trigger stress resistance mechanism) have also been reported [33].

It is crucial to assess the potential effects of seed pretreatments on subsequent seedling performance on the off chance that detrimental effects outweigh the beneficial effects on germination [34]. In our previous studies, we characterised the mechanisms of ageing and reinvigoration of cabbage (Brassica oleraceae) and lettuce (Lactuca sativa) seeds using exogenous antioxidant [17] and inorganic salt [15] solutions. The present study assessed seed ageing rates and patterns in both species. It also investigated whether the beneficial effects of invigorating aged seeds with selected antioxidants, viz. glycerol, reduced glutathione (GSH), and trolox translate to enhanced subsequent seedling performance (in terms of emergence, growth, light-harvesting capacity, total chlorophyll, $\mathrm{CO}_{2}$ assimilation rate, leaf gas exchange and chlorophyll fluorescence) in both species. These variables can be useful in identifying factors that promote recovery from ageing-induced oxidative stress and enhance the performance of seedlings raised from aged seeds of both species 
in field circumstances. Controlled deterioration was used to simulate seed ageing, and a greenhouse pot trial was used to mimic field conditions.

\section{Materials and Methods}

The present study was carried out in two major parts, viz. characterisation of seed ageing rates and patterns via controlled deterioration and assessment of the influence of exogenous antioxidants on subsequent seedling growth, gas exchange, and photochemistry in aged cabbage and lettuce seeds under greenhouse conditions.

\subsection{Characterisation of Seed Ageing Rates and Patterns via Controlled Deterioration \\ 2.1.1. Seed Material}

Commercial seeds of cabbage, 'Glory of Enkhuizen' (Brassica oleracea L.) and lettuce, 'Great Lakes' (Lactuca sativa L.), supplied in air-tight plastic bags (McDonalds Seeds, Pietermaritzburg, South Africa) were maintained at $4{ }^{\circ} \mathrm{C}$ before being utilised for the study. The seeds were used within three months of storage.

\subsubsection{Seed Vigour Assessment}

Seeds were taken from storage at $4{ }^{\circ} \mathrm{C}$ and kept at room temperature overnight before being used. Each seed lot was put through an initial germination and vigour test (three replicates of 25 seeds each) before being subjected to the $\mathrm{CD}$ and antioxidant treatments described below. Only seed lots that showed germination $>85 \%$ (in cabbage) and $>95 \%$ (in lettuce) within $48 \mathrm{~h}$ of sowing were used for subsequent experiments.

\subsubsection{Controlled Deterioration}

Seed moisture content $(\mathrm{MC}, \%)$ was estimated on a fresh weight basis using the International Seed Testing Association (ISTA) validated method for crop seeds [35]. The controlled deterioration experiments followed the ageing methods described by Tekrony [36] with slight modifications. Seed MC (\%) was raised in air-tight plastic boxes $(134 \times 102 \times 70 \mathrm{~mm})$ containing saturated potassium chloride $(\mathrm{KCl})$ solution. The saturated salt solution was made with a slurry of $\mathrm{KCl}(50 \mathrm{~g})$ and deionised water $(20 \mathrm{~mL})$ to produce $85 \%$ relative humidity (RH) at $25^{\circ} \mathrm{C}$ within the plastic box [37]. The $\mathrm{RH}$ and temperature within the plastic boxes were measured using a digital meter (Sinotimer ${ }^{\circledR}$, Wenzhou, China). Seeds were spread evenly on weighing boats which were suspended on a mesh platform about $5 \mathrm{~cm}$ above the saturated solution. Each plastic box lid was lined on the inside with a three-layer blotting paper to prevent dripping of condensed vapour onto the seeds. The seed-containing boxes were kept at $25^{\circ} \mathrm{C}$ for $24 \mathrm{~h}$ to reach the target MC: Seed MC was increased from $5.5 \%$ to $11 \%$ in cabbage and $5.7 \%$ to $11 \%$ in lettuce. Then the seed-containing boxes were moved into an incubator (Heraeus FB 420, Hanau, Germany) set at $35^{\circ} \mathrm{C}$ for CD.

\subsubsection{Germination Test}

Seed germination test was done daily until no germination was recorded. Seeds (4 replicates of 25 seeds each) were taken out of a box in the incubator and sown between two layers of deionised water (DW)-moistened germination paper (Anchor Paper Co., Saint Paul, MN, USA) within Petri dishes and incubated in a growth room at $20 \pm 2{ }^{\circ} \mathrm{C}$, and a photoperiod of 16:8 h (light intensity of about $52 \mu \mathrm{mol}$ photons $\mathrm{m}^{-2} \mathrm{~s}^{-1}$ ). The percentage of normal seedlings produced was recorded 14 days after sowing (DAS). The CD test was conducted twice for both species. The seedling $(\%)$ data were used to construct a CD curve for each species, from which time (days) to 75\% viability (P75), 50\% viability (P50), and $25 \%$ viability (P25) was determined. 


\subsubsection{Seed Ageing Rates and Patterns}

To identify seed ageing rates and patterns, CD curves from the \% normal seedling data were converted to probit values and fitted using the Ellis and Roberts [38] survival curve equation $[39,40]$ :

$$
v=K i-\frac{p}{\sigma},
$$

where,

$v=$ probit of $\%$ final viability after $\mathrm{p}$ days storage,

$p=$ storage duration (days),

$K i=$ intercept, probit of $\%$ initial viability, and

$1 / \sigma=$ slope, which shows the rate of seed deterioration.

The regression analyses of the probit values provided intercepts $(K i)$ and slopes $(1 / \sigma)$ for each CD curve.

\subsection{Assessment of the Influence of Exogenous Antioxidant Invigoration on Subsequent Seedling} Performance of Aged Seeds of Cabbage and Lettuce

\subsubsection{Application of Exogenous Antioxidant Solutions}

Previously, studies [17] were conducted to optimise the treatment concentration and duration of application of a variety of compounds with antioxidative properties on P25 seeds of both cabbage and lettuce. Based on the results of those experiments, the treatments selected for the present study were those that resulted in the highest production of normal seedlings relative to seeds soaked in DW at P25 in both species. These treatments were $0.4 \mathrm{mM}$ glycerol, $0.6 \mathrm{mM}$ glutathione (GSH), and $0.2 \mathrm{mM}$ trolox for cabbage; and $0.6 \mathrm{mM}$ glycerol, $0.6 \mathrm{mM} \mathrm{GSH}$, and $0.6 \mathrm{mM}$ trolox for lettuce. Sixty P25 seeds of each species were soaked for $6 \mathrm{~h}$ in $3 \mathrm{~mL}$ of antioxidant solution or DW (control). The seeds were then removed from the soaking solution, blotted dry with a paper towel, and assessed for germination in a greenhouse as described below.

\subsubsection{Greenhouse Pot Trial}

The pot trials for germination, seedling establishment, and subsequent growth parameters were conducted during the spring of $2019\left(25 \pm 2{ }^{\circ} \mathrm{C}\right.$ and $70 \%$ relative humidity $)$ within a polycarbonate greenhouse $\left(29^{\circ} 49^{\prime} 04.0^{\prime \prime} \mathrm{S}, 30^{\circ} 56^{\prime} 23.5^{\prime \prime} \mathrm{E}\right)$, and the experiment was repeated three times. For each of the three experiments, DW, and antioxidant-treated seeds $(\mathrm{n}=60)$ were sown individually $4-5 \mathrm{~mm}$ deep in $2 \mathrm{~L}$ potting bags filled with equal volumes of potting mix procured from Grovida Horticultural Products (Durban, South Africa). The potting mix was watered to field capacity before sowing and subsequently watered every second day. At 14 DAS, $60 \mathrm{~mL}$ of Fisher's Multifeed ${ }^{\circledR}$ fertiliser $\left(1 \mathrm{~g} \mathrm{~L}^{-1}\right)$ was applied to each pot. Seedling emergence was assessed daily for 14 days. These data were used to calculate seedling emergence percentage (\% E) according to Patil et al. [41], mean emergence time (MET) [42], mean daily emergence (MDE) [43], and time taken to $25 \%$ emergence $\left(\mathrm{T}_{25}\right)$ [44] according to Coolbear et al. [18] as modified by Hussain et al. [45], as follows:

$$
\begin{gathered}
\% \mathrm{E}=\frac{\text { number of emergences }}{\text { number of seeds sown }} * 100, \\
\mathrm{MET}=\frac{\sum \mathrm{Dn}}{\sum \mathrm{n}},
\end{gathered}
$$

where $\mathrm{n}$ is the number of seedlings that emerged on day $\mathrm{D}$, and $\mathrm{D}$ is the number of DAS.

$$
\begin{gathered}
\text { MDE }=\frac{\text { total emergence }(\%)}{\text { number of days to final emergence }}, \\
\mathrm{T}_{25}=\mathrm{ti}+\frac{(\mathrm{N} / 2-\mathrm{ni})(\mathrm{tj}-\mathrm{ti})}{\mathrm{nj}-\mathrm{ni}},
\end{gathered}
$$


where $\mathrm{N}$ is the final number of seedlings emerged, $\mathrm{n}_{\mathrm{i}}$ and $\mathrm{n}_{\mathrm{j}}$ are the total seedling emergence by adjacent counts at times $t_{i}$ and $t_{j}$, respectively, and $n_{i}<N / 2<n_{j}$.

\subsubsection{Seedling Vigour and Biomass Accumulation}

Harvesting of plants and all postharvest measurements were carried out six weeks after sowing when the plants had attained a steady-state [46]. In each experiment, seedlings $(n=10)$ were uprooted, separated into roots and shoots, and the roots were rinsed under running tap water and thereafter blotted dry using blotting paper. Root and shoot lengths $(\mathrm{mm})$ were measured for the calculation of the seedling vigour index (SVI) developed by Abdul-Baki and Anderson [47]:

$$
\mathrm{SVI}=\text { seedling length }(\mathrm{mm}) * \% \text { seedling emergence. }
$$

The roots and shoots were dried in an oven (Gallenkamp Incubator, Model IH-150, London, $\mathrm{UK}$ ) at $80^{\circ} \mathrm{C}$ for three days, and the data were used to calculate the root:shoot ratio.

Leaf area $\left(\mathrm{cm}^{2}\right)$ of the 10 seedlings from each experiment was measured using one young, fully expanded leaf (of the same age) from each seedling. Each leaf was scanned with an HP scanner (HP Scanjet G4050, Model L1957A, Shanghai, China), and the leaf area was estimated with a scientific image analysis program, ImageJ Ver. 1.52a (Rasband W.S., Bethesda, MD, USA). The leaf area ratio was calculated as the ratio of the leaf area to the unit total dry weight of the leaf.

\subsubsection{Leaf Chlorophyll Content, Gas Exchange, and Chlorophyll Fluorescence}

Total chlorophyll was measured in five seedlings using a hand-held Soil Plant Analysis Development (SPAD) chlorophyll meter (Konica Minolta SPAD-502, Tokyo, Japan). The measurements were taken at the tip and on either side of the midrib of one of the second youngest, fully expanded leaves of each seedling, and the average reading was recorded for each leaf in SPAD units.

Photosynthetic rate (Pn), stomatal conductance (Gs), and transpiration rate (E) were measured on five seedlings using a portable photosynthesis and chlorophyll fluorescence system (Li-6400, LI-COR, Lincoln, NE, USA) between 11:00 and 13:00 when seedlings were six weeks old. Measurements were taken on one of the second youngest, fully expanded leaves per seedling for each experiment. Using the same instrument, chlorophyll fluorescence taken as the maximum quantum yield of PSII photochemistry $\left(\mathrm{F}_{\mathrm{v}} / \mathrm{F}_{\mathrm{m}}\right)$ was measured in five seedlings. Seedlings were subjected to dark adaptation for at least $1 \mathrm{~h}$ prior to measurements for electrons to drain off the photosystems [48-50]. One measurement was taken on one of the second youngest leaves per seedling. Leaves exposed to chlorophyll fluorescence measurements were not reused for other readings.

\subsection{Statistical Analysis}

Data were analysed with IBM SPSS Statistics (Ver. 26.0. Armonk, NY, USA). ShapiroWilk was used to test for normality. Percentage data were arcsine transformed before analysis. The rates of seed deterioration in both species were compared by $\mathrm{t}$-test. Seedling performance data were tested for differences by ANOVA where data were parametric, and a Tukey post-hoc test was used to separate means. A Kruskal-Wallis test was used where data were nonparametric. Differences were considered significant at 0.05 level.

\section{Results}

\subsection{Characterisation of Seed Ageing Rates and Patterns via Controlled Deterioration}

Unaged seeds of both cabbage and lettuce showed a high germinability $(>95 \%)$ within $48 \mathrm{~h}$. When subjected to controlled deterioration (CD), cabbage seeds initially (days 0 to 2) exhibited no loss of vigour (asymptomatic phase) and maintained high initial normal seedling production (Figure 1A). The asymptomatic phase was followed by a progressive 
decline in normal seedling production, with seeds reaching P75, P50, and P25 more or less on days 6,13 , and 17 , respectively. This yielded deterioration rates of $0.13 \pm 0.01$, $0.15 \pm 0.01$, and $0.15 \pm 0.01$ probit/day, respectively (Table 1 ). All viability was lost by day 28. Relative to cabbage seeds, lettuce seeds exhibited a much longer asymptomatic phase when subjected to CD, with no loss of vigour recorded for 9 days (Figure 1B). The asymptomatic phase was followed by a rather steep decline in viability, with P75, P50, and P25 being reached more or less on days 10,11, and 13, respectively. This resulted in higher rates of deterioration $(0.47 \pm 0.02$ probit/day for P75; $0.47 \pm 0.02$ probit/day for P50; and $0.48 \pm 0.02$ probit/day for P25) (Table 1) than cabbage under the same CD conditions. This was also evidenced by the fact that total viability loss in lettuce was recorded 9 days (day 19) earlier than in cabbage.
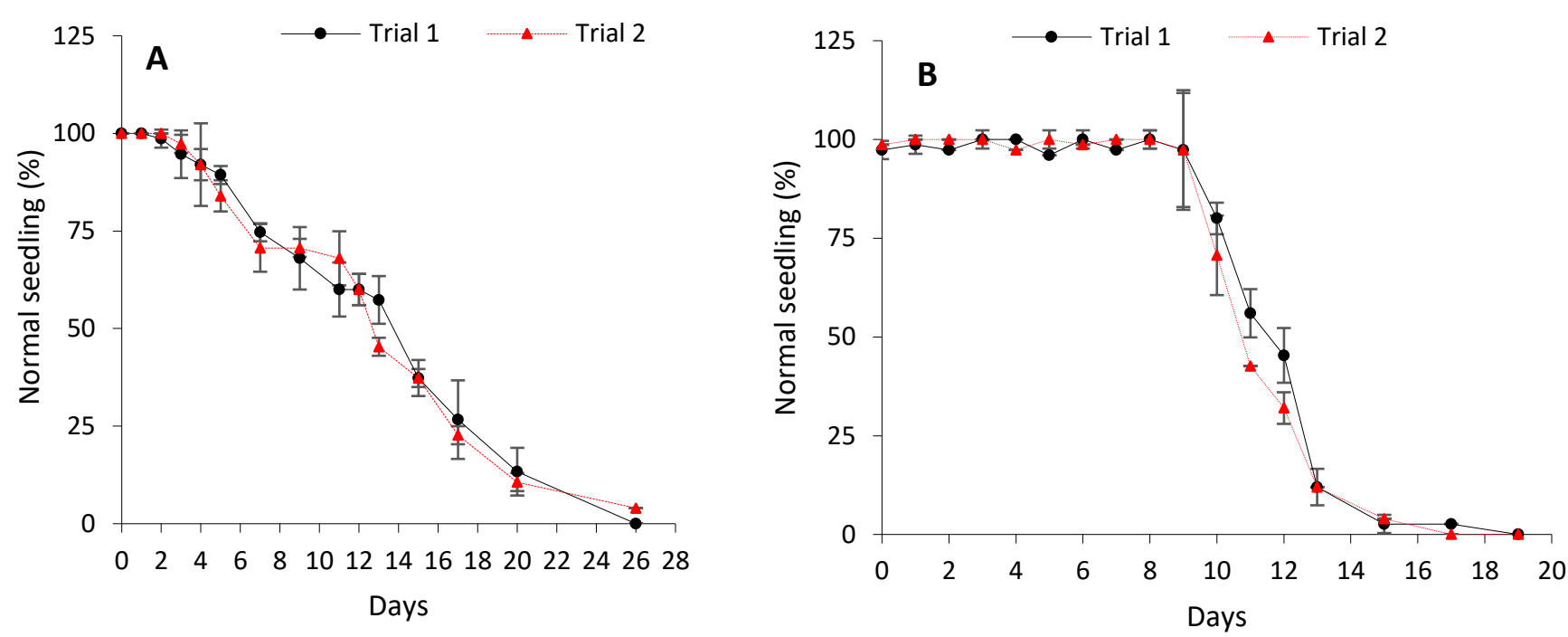

Figure 1. Controlled deterioration curves for cabbage (B. oleracea) (A) and lettuce (L. sativa) (B). Data points represent mean $\pm \mathrm{SD}(4 \times \mathrm{n}=25)$. The experiment was repeated twice for both species.

Table 1. Rate of deterioration in cabbage and lettuce seeds subjected to controlled deterioration (CD).

\begin{tabular}{ccc}
\hline CD Level & $\begin{array}{c}\text { Cabbage Seed Deterioration } \\
\text { Rate (Probit/Day) }\end{array}$ & $\begin{array}{c}\text { Lettuce Seed Deterioration } \\
\text { Rate (Probit/Day) }\end{array}$ \\
\hline P75 & $0.13 \pm 0.01^{\mathrm{b}}$ & $0.47 \pm 0.02^{\mathrm{a}}$ \\
P50 & $0.15 \pm 0.01^{\mathrm{b}}$ & $0.47 \pm 0.02^{\mathrm{a}}$ \\
P25 & $0.15 \pm 0.01^{\mathrm{b}}$ & $0.48 \pm 0.02^{\mathrm{a}}$
\end{tabular}

Values represent the mean \pm SD (2 trials) of the rate of viability loss in cabbage (B. oleracea) and lettuce (L. sativa) seeds subjected to controlled deterioration. Values labelled with different letters are significantly different $(p<0.05$, t-test) when compared across species within each CD level.

\subsection{Effect of Exogenous Application of Antioxidants on Seedling Emergence Parameters of Controlled Deteriorated Cabbage and Lettuce Seeds}

The study showed that seedling emergence, mean emergence time (MET), mean daily emergence (MDE), and time to $25 \%$ emergence $\left(\mathrm{T}_{25}\right)$ were not influenced significantly by the exogenously applied antioxidants in both cabbage (Figure 2A-D) and lettuce seeds (Figure $2 \mathrm{E}-\mathrm{H}$ ) relative to DW-soaked seeds. 

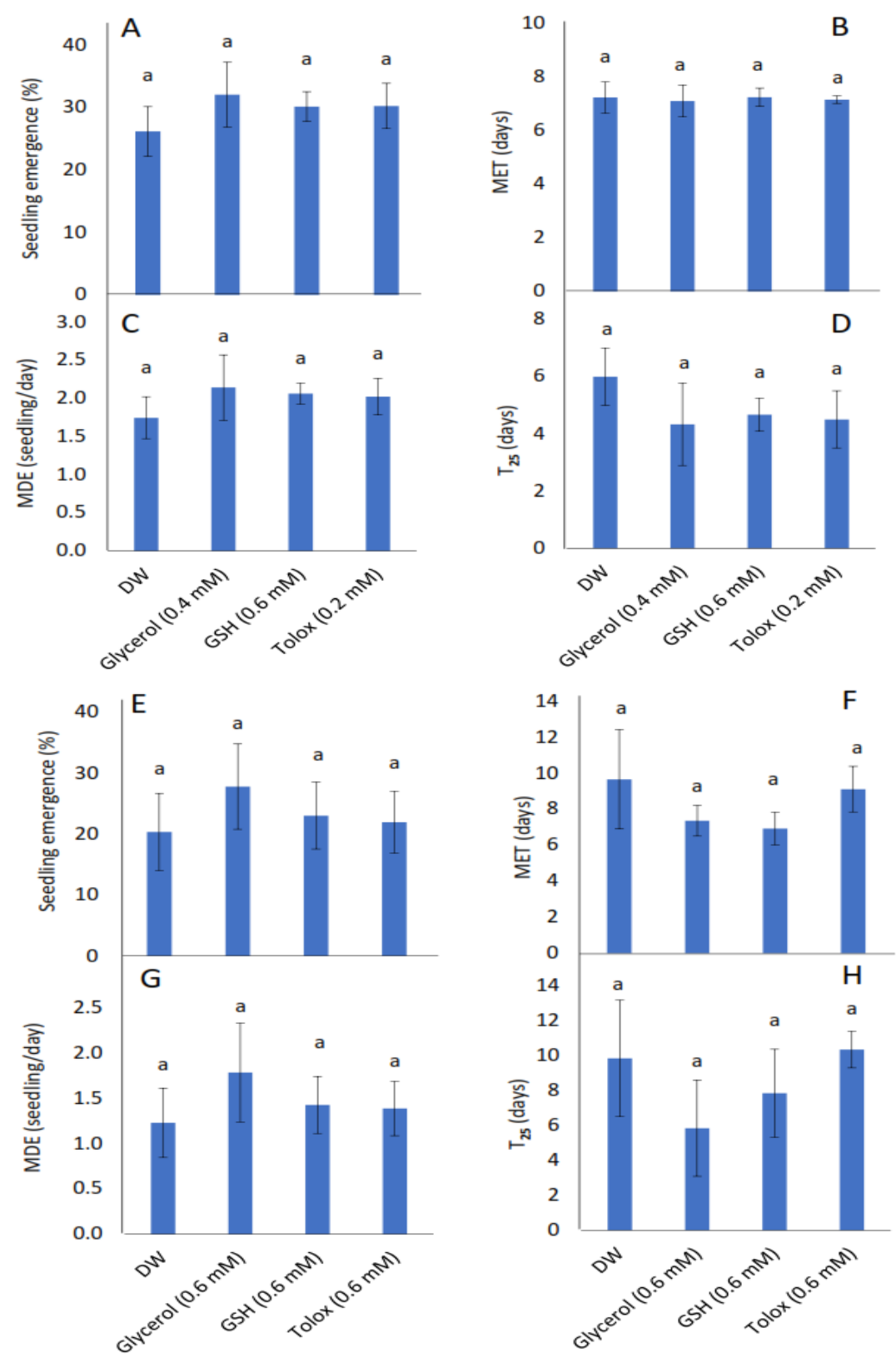

Figure 2. Effect of exogenous application of antioxidants on seedling emergence parameters: \% seedling emergence (A,E), mean emergence time (MET) $(\mathbf{B}, \mathbf{F})$, mean daily emergence (MDE) $(\mathbf{C}, \mathbf{G})$, and time taken to $25 \%$ emergence $\left(\mathrm{T}_{25}\right)(\mathbf{D}, \mathbf{H})$ from $\mathrm{P} 25$ seeds of cabbage (B. oleracea) $(\mathbf{A}-\mathbf{D})$ and lettuce (L. sativa) (E-H) subjected to soaking in deionised water (DW), glycerol, glutathione (GSH) or trolox. Values represent mean $\pm \mathrm{SD}(3 \times \mathrm{n}=60)$. Bars labelled with the same letters indicate no significant differences across the control (DW) and antioxidant treatments for all four parameters $(p<0.05$, ANOVA)

\subsection{Effect of Exogenous Application of Antioxidants on Seedling Vigour and Biomass} Accumulation of Seedlings Produced from Controlled Deteriorated Cabbage and Lettuce Seeds

Seedling vigour index (SVI) increased significantly in P25 cabbage seeds soaked in glycerol $(0.4 \mathrm{mM})$ and GSH $(0.6 \mathrm{mM})$, and in P25 lettuce seeds soaked in glycerol $(0.6 \mathrm{mM})$, relative to DW-soaked seeds (Figure 3A,E, respectively). Root dry weight, however, was not influenced significantly by the application of exogenous antioxidants in both cabbage and lettuce seeds relative to DW-soaked seeds (Figure 3B,F, respectively). Although shoot dry weight was not influenced significantly by the application of exogenous antioxidants in P25 cabbage seeds, it increased significantly in P25 lettuce seeds treated with glycerol 
relative to DW-soaked seeds (Figure 3C,G, respectively). The root:shoot ratio was not influenced significantly by the application of exogenous antioxidant solutions in P25 seeds of both species relative to DW-soaked seeds (Figure 3D,H, respectively).
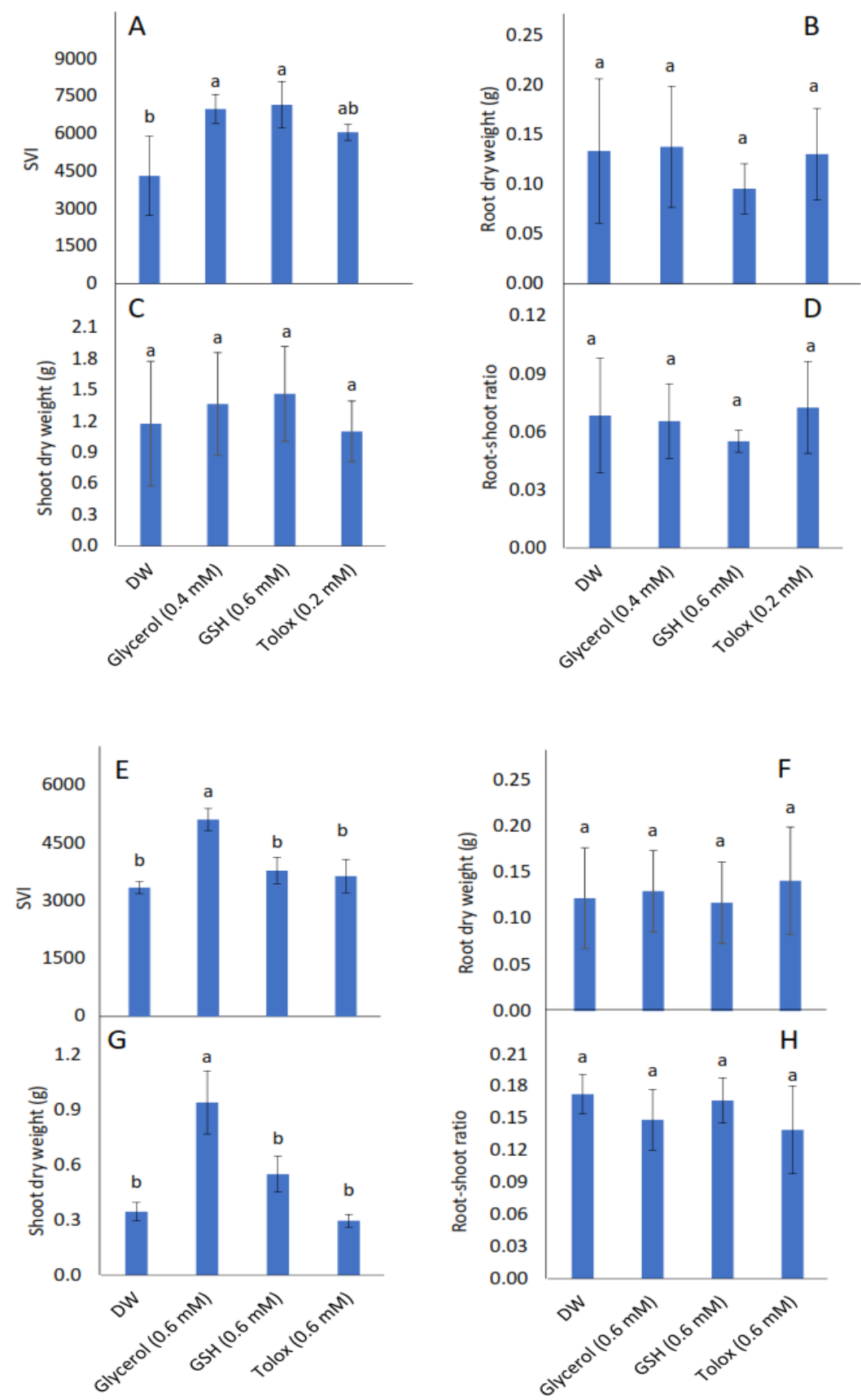

Figure 3. Effect of exogenous application of antioxidants on seedling vigour index (SVI) (A,E), root dry weight $(\mathbf{B}, \mathbf{F})$, shoot dry weight $(\mathbf{C}, \mathbf{G})$, and root:shoot ratio $(\mathbf{D}, \mathbf{H})$ in seedlings produced from $\mathrm{P} 25$ seeds of cabbage (B. oleracea) (A-D) and lettuce (L. sativa) (E-H) subjected to soaking in deionised water $(\mathrm{DW})$, glycerol, glutathione $(\mathrm{GSH})$ or trolox. Values represent mean $\pm \mathrm{SD}(3 \times n=10)$. Bars labelled with different letters indicate significant differences $(p<0.05$, ANOVA).

3.4. Effect of Exogenous Application of Antioxidants on Leaf Area, Leaf Area Ratio, and Total Chlorophyll Content of Leaves from Seedlings Produced from Controlled Deteriorated Cabbage and Lettuce Seeds

Leaf area increased significantly in the seedlings produced from both P25 cabbage and lettuce seeds treated with glycerol $(0.4 \mathrm{mM}$ and $0.6 \mathrm{mM}$, respectively) relative to 
DW-soaked seeds (Figure 4A,D, respectively). However, in both species, the leaf area ratio (Figure 4B,E, respectively), and total chlorophyll contents (Figure 4C,F, respectively) were not significantly influenced by the exogenously applied antioxidants when compared with DW-soaked seeds.
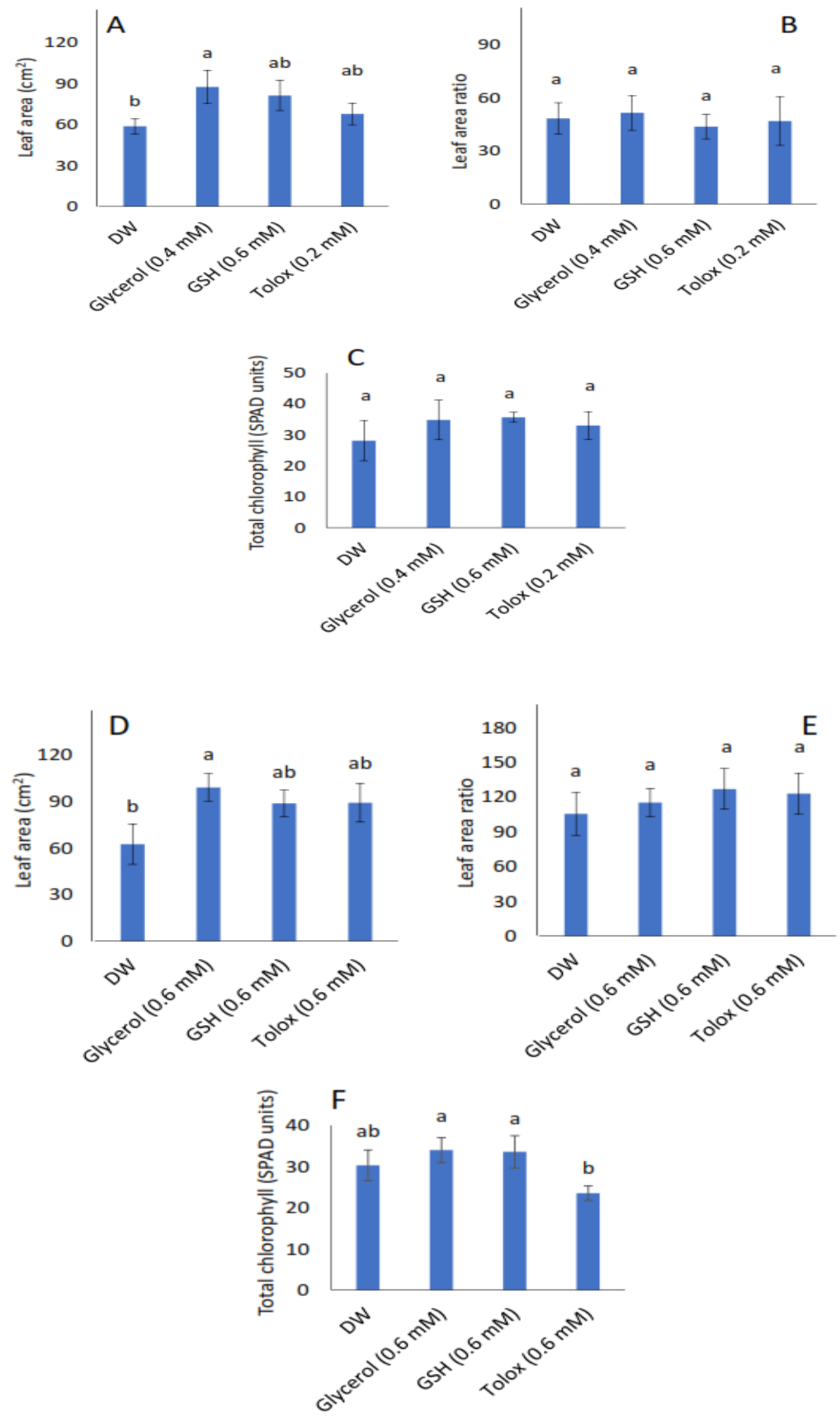

Figure 4. Effect of exogenous application of antioxidants on leaf area $(\mathbf{A}, \mathbf{D})$, leaf area ratio $(\mathbf{B}, \mathbf{E})$, and total chlorophyll $(\mathbf{C}, \mathbf{F})$ in seedlings produced from $\mathrm{P} 25$ seeds of cabbage (B. oleracea) $(\mathbf{A}-\mathbf{C})$ and lettuce (L. sativa) (D-F) subjected to soaking in deionised water (DW), glycerol, glutathione (GSH) or trolox. Values represent mean $\pm \mathrm{SD}(3 \times \mathrm{n}=10$ for leaf area; $\mathrm{n}=5$ for total chlorophyll). Bars labelled with different letters indicate significant differences $(p<0.05$, ANOVA).

3.5. Effect of Exogenous Application of Antioxidants on Photosynthetic Rate, Gas Exchange, and Photochemistry of Seedlings Produced from Controlled Deteriorated Cabbage and Lettuce Seeds

All parameters investigated, viz. seedling photosynthetic rate (Pn), stomatal conductance (Gs), transpiration rate (E), and maximum quantum yield of PSII photochemistry 
$\left(\mathrm{F}_{\mathrm{v}} / \mathrm{F}_{\mathrm{m}}\right)$ were not significantly influenced by the exogenous application of antioxidants in P25 cabbage seeds (Figure 5A-D). In seedlings produced from P25 lettuce seeds, however, the photosynthetic rate significantly increased when the seeds were soaked in $0.6 \mathrm{mM}$ of glycerol, GSH, and trolox relative to DW-treated seeds (Figure 5E). Stomatal conductance increased significantly when these seeds were soaked in $0.6 \mathrm{mM}$ of glycerol and GSH (Figure 5F). Similarly, transpiration rate increased significantly in P25 lettuce seeds treated with $0.6 \mathrm{mM}$ of glycerol, GSH, and trolox, relative to DW-treated seeds (Figure 5G). The maximum quantum yield of PSII photochemistry was not significantly increased when P25 lettuce seeds were treated with antioxidants relative to DW-treated seeds (Figure 5H).
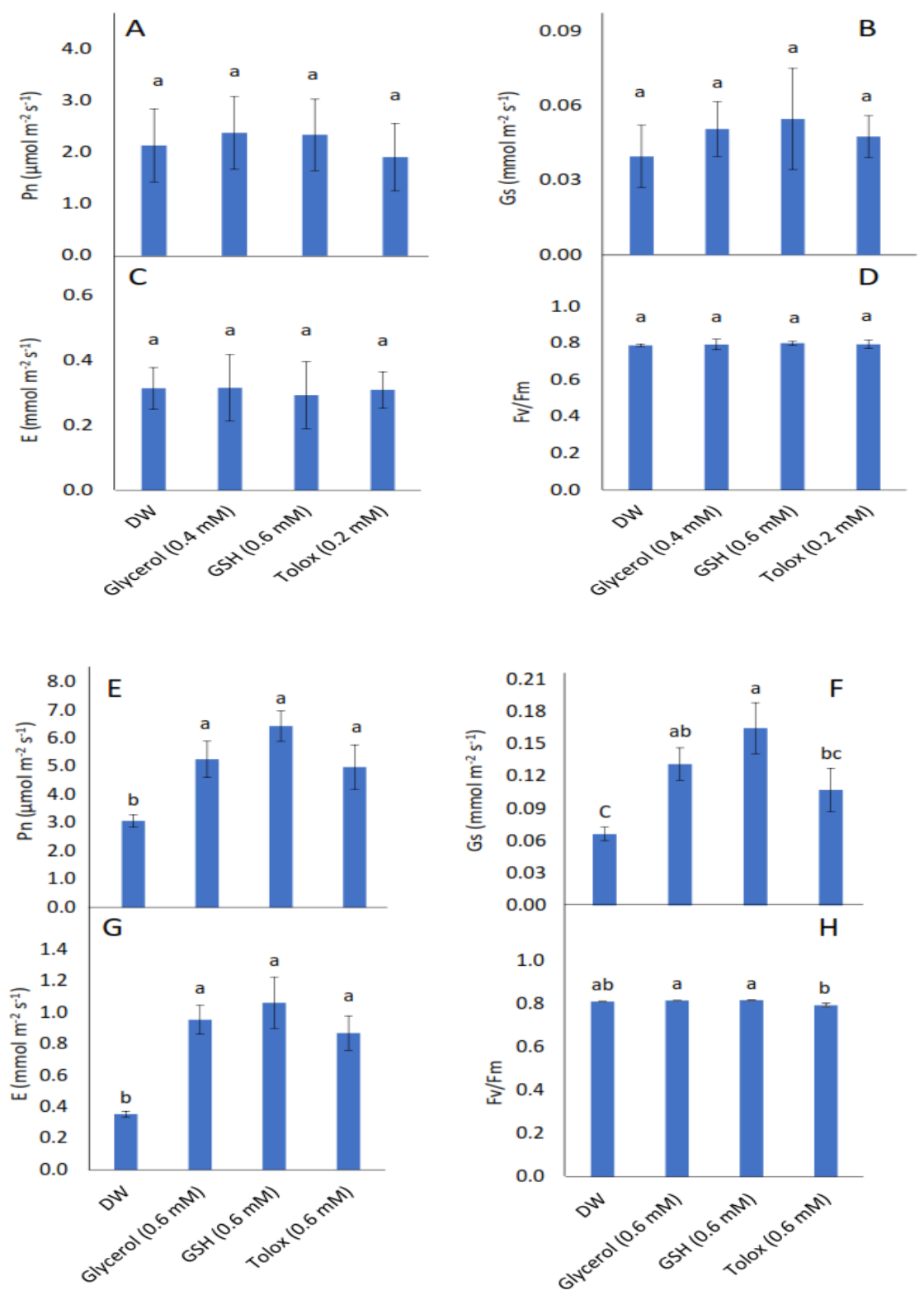

Figure 5. Effect of exogenous application of antioxidants on photosynthetic rate (Pn) (A,E), stomatal conductance $(\mathrm{Gs})(\mathbf{B}, \mathbf{F})$, transpiration rate $(\mathrm{E})(\mathbf{C}, \mathrm{G})$, and chlorophyll fluorescence $\left(\mathrm{F}_{\mathrm{v}} / \mathrm{F}_{\mathrm{m}}\right)(\mathbf{D}, \mathbf{H})$ in seedlings produced from P25 seeds of cabbage (B. oleracea) (A-D) and lettuce (L. sativa) (E-H) subjected to soaking in deionised water (DW), glycerol, glutathione (GSH) or trolox. Values represent mean $\pm \mathrm{SD}(3 \times \mathrm{n}=5)$. Bars labelled with different letters indicate significant differences $(p<0.05$, ANOVA). 


\section{Discussion}

\subsection{Differences in Rates and Patterns of Ageing in Cabbage and Lettuce Seeds Subjected to Controlled Deterioration}

Understanding the differences in seed deterioration rates and storability is vital for effective management of seed collections and conservation as it is useful in the selection of intervals for viability retesting and thus recollection or regeneration strategies [51,52]. As seeds deteriorate over time, two distinct phases are observable: the ageing resistance phase, during which high and reasonably steady germination is recorded, and the ageing susceptibility phase marked by a rapid loss of ageing resistance and viability [53]. In the present study, cabbage seeds subjected to $C D$ had a short (2 days) ageing resistance (asymptotic) phase and an extended period (28 days) of deterioration ending in total viability loss (Figure 1A). However, although this rate of deterioration (in terms of probit/day for P75, P50, and P25) was significantly slower than that observed for controlled deteriorated lettuce seeds (Table 1 ), lettuce seeds had a more prolonged (9 days) ageing resistance phase and exhibited a much shorter time (19 days) to reach total viability loss (Figure 1B). These results indicate differences in the rate of seed deterioration between both species when subjected to CD; perhaps, due to differences in the type and degree of damage incurred.

The ageing pattern observed here is typical of high vigour seeds with initial high ageing resistance during cold storage [54], high temperature [55] or accelerated ageing experimental conditions [56] in which a plateau at the early phase of a survival curve is recognisable. Whilst high vigour seeds can maintain a high germination percentage for decades under low-temperature storage in gene banks, making their deterioration (in terms of loss of vigour/ageing resistance) hard to assess, seed deterioration progresses at varying rates towards eventual loss of viability. Once seeds with high viability become susceptible to ageing, they tend to suffer a loss of viability quickly afterwards, owing to the accumulation of ROS [53]. The reports of previous studies have suggested differences in the rate of seed deterioration in storage across species and among even cultivars of related species $[57,58]$ and seed lots within a species [38] in relation to their condition of storage. For instance, Walters et al. [59] reported variations in the rate of seed deterioration in terms of viability loss in about 276 species and 207 cultivars from 42 species, including lettuce under cold storage in gene banks. Saxena et al. [60] reported differences in the rate of vegetable seed deterioration among species in the Brassicaceae family, including cabbage stored under room temperature. Lee et al. [52] reported variations in the rate of viability loss in 42 plant species stored for 10 years in "midterm storage $\left(4^{\circ} \mathrm{C}, 30-40 \% \mathrm{RH}\right)$ ". They imputed the variations in seed deterioration rate to the chemical and genetic make-up, which outfitted some species for prolonged storability than the others under the same storage conditions.

Seed ability to resist deterioration is thought to be controlled in some way by several genes distributed all through the genome and is greatly affected by environmental factors [61]. These environmental factors include but are not limited to postharvest processing [62] and storage environment, particularly temperature and relative humidity [63,64], and seed moisture content [21], which influences the deterioration rate under air-dry storage condition $[65,66]$. Seeds suffer a rapid loss of ageing resistance with increasing seed moisture level and storage temperature [65,67-69]. Other factors, such as parental environment [70], harvest timing [71], the physical state and physiological condition of seeds $[66,72]$ have also been reported to influence seed deterioration. The variation in seed deterioration rate may or may not be due to differences in ageing mechanisms; where the former is the case, the effects of invigorative interventions could also differ.

\subsection{Influence of Exogenous Antioxidant Invigoration of Aged Cabbage and Lettuce Seeds on} Subsequent Seedling Emergence, Growth, Gas Exchange, and Photochemistry

Previous studies on the effects of exogenous application of antioxidants on seed performance mostly show promotive effects such as improved speed of emergence, seedling growth, and/or yield $[31,73,74]$. For instance, soaking of unaged rice grains in antioxidants 
including trolox (tocopherol) promoted germination [75], while the use of glycerol as an osmotic treatment enhanced germination rate in unaged celery (Apium graveolens), leek (Allium ampeloprasum) and onion (Allium cepa), \% seedling emergence in celery seeds, and mean emergence time in all species [76]. It should be noted that in the same study, however, glycerol did lead to a reduction in carrot (Daucus carota) \% seedling emergence. The use of exogenously applied antioxidants in the present study not only differs from the above studies in that the antioxidant solutions were exogenously applied to aged cabbage and lettuce seeds, but also the effects on seedling emergence parameters appeared to be neither promotive nor detrimental relative to DW-treated seeds (Figure 2A-H, respectively). While Yousof et al. [75] showed that seed hydration in tocopherol before sowing did not change the mean germination time and time taken to $50 \%$ germination in unaged rice grains, Draganić and Lekić [24] reported reduced germination in sunflower seeds subjected to accelerated ageing after hydration treatment with AA, GSH and tocopherol.

Despite the lack of effect on seedling emergence parameters in this study, the exogenously applied antioxidants significantly influenced seedling growth in both species. More specifically, glycerol enhanced SVI in P25 cabbage and lettuce seeds (Figure 3A,E, respectively) and enhanced shoot biomass in P25 lettuce seeds (Figure 3G), while GSH enhanced SVI in P25 cabbage seeds only (Figure 3A). The promotive effects on SVI and shoot biomass may be attributed to improved physiological functions during the early stages of development, possibly owing to enhanced antioxidant protection. Previous studies have shown similar promotive effects of several exogenously applied antioxidants on SVI and biomass accumulation. In the study by Roopa et al. [29], for example, the exogenous application of glycerol to pearl millet (Pennisetum glaucum) seeds promoted SVI, seedling height and shoot dry weight.

Other examples of the stimulatory effect of exogenously applied antioxidants on seedling growth after seed hydration exist in the literature: sunflower shoot length increased when seeds were treated with AA, GSH, and tocopherol [24]. In another study, canola (Brassica napus) and sunflower root and shoot length and dry weight, and seedling dry weight were increased when seeds were pre-hydrated with AA [77]. The authors opined that the promotive effects might be a consequence of the enhancement of cell division and differentiation of meristematic cells. It has been said that the exogenous application of antioxidants may have diverse effects on several plant metabolic and physiological processes, including germination and uptake and transport of ions [77]. Exogenous application of antioxidants has also been shown to promote plant growth in terms of vigour and yield by enhancing nutrient uptake and increasing stress tolerance [31], possibly through enhanced antioxidant defence [74] during the early stages of seedling development when seedlings are quite vulnerable to stress. This not only helps in effective seedling recruitment but also increases yield, which is highly beneficial.

Given that plant leaves are the main organs associated with photosynthesis in a plant, leaf area has a direct effect on plant photosynthetic performance and growth [78]. The leaf area defines the light-harvesting capacity and is, therefore, a useful index for evaluating plant growth [78-80]. In the present study, seed treatment of P25 cabbage and lettuce seeds with certain antioxidants had a significant effect on leaf area in the seedlings subsequently produced by both species: glycerol enhanced leaf area in seedlings produced by both P25 cabbage and lettuce seeds (Figure 4A,D, respectively) relative to DW-treated seeds. However, the leaf area ratio and total chlorophyll content were not significantly affected in both species (Figure 4B,C,E,F, respectively). Similarly, in a greenhouse and field study on pearl millet seeds, the application of glycerol as a pre-hydration treatment led to increased leaf area in the seedlings produced [29]. As observed in the present study, the promotive effect of glycerol may be linked to the reported stimulatory effects on the activities of certain enzymes involved in photosynthesis, such as phosphoenolpyruvate carboxylase [81]. Seed pre-hydration treatment with other exogenous antioxidants such as AA has also been suggested to enhance the retention of stay-green traits, eventually leading to more leaf area to capture radiant energy in winter wheat [31]. 
High growth rates are generally accompanied by high photosynthetic efficiency $[11,82]$. In the present study, the effects of seed pretreatment with antioxidants did affect gas exchange, but these effects were limited to lettuce. Gas exchange and chlorophyll fluorescence in seedlings produced from P25 cabbage seeds were statistically comparable to seedlings produced from DW-treated seeds (Figure 5A-D). In contrast, pretreatment of P25 lettuce seeds with glycerol and GSH enhanced Pn, Gs, and E of the seedlings compared with those produced from seeds treated with DW (Figure 5E-G). However, Fv / Fm in seedlings was not significantly affected by any antioxidant treatment (Figure 5H). Pretreatment of P25 lettuce seeds with trolox also enhanced Pn and E in the seedlings produced. Increased Gs often leads to increased Pn and E [83-87], but Pn can be enhanced through non-stomatal effects as well [88], which appears to have been the case in seedlings produced from troloxtreated seeds. In a previous study on the oxidative stress effects of drought on seeds of two wheat genotypes, seed pre-hydration with the antioxidant AA, enhanced photosynthetic parameters, including Pn [30]. As alluded to earlier, the early seedling development stage is particularly susceptible to oxidative stress [89], which may affect genome integrity, seed quality, and viability. Although naturally occurring antioxidant molecules should operate as ROS scavengers, seeds subjected to ageing may suffer irreversible damage. The provision of antioxidants through seed pretreatment may bolster antioxidant protection during the early development stage, thereby mitigating the injurious effects of oxidative stress such as the impairment of chloroplast thylakoid membranes and reaction centres [90-92]. Photosynthetic processes, even under favourable conditions, are intrinsically accompanied by the generation of high levels of cellular oxidants such as hydrogen peroxide, superoxide radical, and singlet oxygen through the functioning of the electron transport chain in chloroplasts [93-95]. An efficient antioxidant defence system, comprising of antioxidative enzymes as well as antioxidants such as GSH, $\alpha$-tocopherol, etc., is required to prevent toxic concentrations of reactive oxygen species in the chloroplasts [93], which could lead to photo-oxidative injury to photosynthetic apparatus and consequently reduced plant growth.

\section{Conclusions}

This study showed that seed ageing resulted in the loss of vigour and viability in both species but at different rates. The differences in seed deterioration rates emerged despite subjecting both species (with similarly high initial viability of $>85 \%$ ) to the same $\mathrm{CD}$ conditions. This suggests interspecies differences in the mechanisms of ageing, as we previously characterised [17], and might be the case for other orthodox crop species. In the asymptotic phase, the loss of resistance to ageing was hard to recognise owing to the lack of a visible change in normal seedling production, even though the reduction in normal seedling production was of significant interest and not difficult to detect. Whether the loss of ageing resistance occurs before recognisable changes in normal seedling production, particularly in lettuce seeds, is worth investigating in greater detail. Monitoring seed ageing resistance, as well as seed vigour, and viability may help identify early deterioration signs and proper timing for earlier invigorative intervention to improve ageing resistance and prolong storability. Other researchers also recommend that characterising nonlethal injury within seeds may allow for the detection of early deterioration signs and accurate prediction of storability [55].

In the pot trial, seed pretreatment with antioxidants had a positive influence on growth in both species and shoot dry weight, gas exchange and $\mathrm{CO}_{2}$ assimilation rate in lettuce. Importantly, glycerol enhanced seedling vigour and light-harvesting capacity (i.e., leaf area) in both species and increased shoot dry weight in lettuce. Additionally, glycerol and GSH stimulated Pn, Gs, and E, while trolox enhanced Pn and E in lettuce. These promotive effects of seed pretreatment with antioxidants on plant growth demand further investigation, considering that it could be used to alleviate poor stand establishment and other major metabolic consequences of seed ageing during germination and early seedling growth. 
Author Contributions: A.E.A. did the experimental work, analysed the data and wrote the original manuscript as supervised by S., B.V. and N.W.P. All authors have read and agreed to the published version of the manuscript.

Funding: This work was supported by the National Research Foundation (Grant Holder Bursary), South Africa [grant number CPRR13092145823]. The APC was partially funded by the University of KwaZulu-Natal, South Africa.

Data Availability Statement: No additional data supporting results of the study were discussed. All data used for the study were repored in the manuscript.

Conflicts of Interest: The authors declare no conflict of interest.

\section{References}

1. Rakshit, A.; Singh, H.B. (Eds.) Advances in Seed Priming; Springer: Singapore, 2018; ISBN 978-981-13-0031-8.

2. Johnson, R.R.; Wax, L.M. Relationship of soybean germination and vigor tests to field performance. Agron. J. 1978, 70, $273-278$. [CrossRef]

3. Heydecker, W. Vigour. In Viability of Seeds; Roberts, E.H., Ed.; Springer: Dordrecht, The Netherlands, 1972; pp. $209-252$.

4. Hall, R.D.; Wiesner, L.E. Relationship between seed vigor tests and field performance of 'regar' meadow bromegrass. Crop Sci. 1990, 30, 967-970. [CrossRef]

5. Mehrabadi, M.; Bandani, A.R. Assessing of $\alpha$-amylase activity of midgut in wheat bug Eurygaster Maura. Am. J. Appl. Sci. 2009, 6, 478-483. [CrossRef]

6. Matthews, S.; Collins, M.T. The effect of seed condition and fungicidal dressings on the field emergence of barley. In Proceedings of the 7th British Insecticide and Fungicide Conference, Brighton, UK, 19-22 November 1973; British Crop Protection Council: Nottingham, UK; pp. 135-141.

7. Perry, D.A.; Harrison, J.G. Effects of seed deterioration and seed-bed environment on emergence and yield of spring-sown barley. Ann. Appl. Biol. 1977, 86, 291-300. [CrossRef]

8. Stormonth, D.A.; Doling, D.A. The significance of seed vigour in cereals. Arab. Farm. 1979, 6, 42-46.

9. Mirmazloum, I.; Kiss, A.; Erdélyi, É.; Ladányi, M.; Németh, É.Z.; Radácsi, P. The Effect of osmopriming on seed germination and early seedling characteristics of Carum carvi L. Agriculture 2020, 10, 94. [CrossRef]

10. Kolasinska, K.; Szyrmer, J.; Dul, S. Relationship between laboratory seed qality tests and field emergence of common bean seed. Crop Sci. 2000, 40, 470-475. [CrossRef]

11. Lubbe, E.; Rodda, N. Sershen Effects of greywater irrigation on germination, growth and photosynthetic characteristics in selected African leafy vegetables. Water SA 2016, 42, 203-212. [CrossRef]

12. Wilson Jr, D.O.; McDonald Jr, M.B. Lipid peroxidation model of seed ageing. Seed Sci. Technol. 1986, 14, $269-300$.

13. Chang, S.M.; Sung, J.M. Deteriorative changes in primed sweet corn seeds during storage. Seed Sci. Technol. 1998, $26,613-625$.

14. Sahu, B.; Sahu, A.K.; Thomas, V.; Naithani, S.C. Reactive oxygen species, lipid peroxidation, protein oxidation and antioxidative enzymes in dehydrating Karanj (Pongamia pinnata) seeds during storage. South African J. Bot. 2017, 112, 383-390. [CrossRef]

15. Adetunji, A.E.; Sershen; Varghese, B.; Pammenter, N.W. Effects of inorganic salt solutions on vigour, viability, oxidative metabolism and germination enzymes in aged cabbage and lettuce seeds. Plants 2020, 9, 1164. [CrossRef] [PubMed]

16. Mira, S.; Estrelles, E.; González-Benito, M.E.; Corbineau, F. Biochemical changes induced in seeds of Brassicaceae wild species during ageing. Acta Physiol. Plant. 2011, 33, 1803-1809. [CrossRef]

17. Adetunji, A.E.; Sershen; Varghese, B.; Pammenter, N. Effects of exogenous application of five antioxidants on vigour, viability, oxidative metabolism and germination enzymes in aged cabbage and lettuce seeds. South African J. Bot. 2021, 137, 85-97. [CrossRef]

18. Coolbear, P.; Francis, A.; Grierson, D. The effect of low temperature pre-sowing treatment on the germination performance and membrane integrity of artificially aged tomato seeds. J. Exp. Bot. 1984, 35, 1609-1617. [CrossRef]

19. Khan, M.M.; Iqbal, M.J.; Abbas, M.; Usman, M. Effect of ageing on viability, vigour and chromosomal damage in pea (Pisum sativum L.) seeds. Pakistan J. Agric. Sci. 2003, 40, 50-54.

20. Berjak, P.; Villiers, T.A. Ageing in plant embryos. New Phytol. 1972, 71, 1069-1074. [CrossRef]

21. Merritt, D.J.; Senaratna, T.; Touchell, D.H.; Dixon, K.W.; Sivasithamparam, K. Seed ageing of four Western Australian species in relation to storage environment and seed antioxidant activity. Seed Sci. Res. 2003, 13, 155-165. [CrossRef]

22. Shaban, M. Review on physiological aspects of seed deterioration. Int. J. Agric. Crop Sci. 2013, 6, 627-631.

23. Yan, H.-F.; Mao, P.-S.; Sun, Y.; Li, M.-L. Impacts of ascorbic acid on germination, antioxidant enzymes and ultrastructure of embryo cells of aged Elymus sibiricus seeds with different moisture contents. Int. J. Agric. Biol. 2016, 18, 176-183. [CrossRef]

24. Draganić, I.; Lekić, S. Seed priming with antioxidants improves sunflower seed germination and seedling growth under unfavorable germination conditions. Turkish J. Agric. For. 2012, 36, 421-428. [CrossRef]

25. Xia, F.; Cheng, H.; Chen, L.; Zhu, H.; Mao, P.; Wang, M. Influence of exogenous ascorbic acid and glutathione priming on mitochondrial structural and functional systems to alleviate aging damage in oat seeds. BMC Plant Biol. 2020, 20, 1-11. [CrossRef] [PubMed] 
26. Chakrabarti, M.C.; Le, N.; Paik, C.H.; De Graff, W.G.; Carrasquillo, J.A. Prevention of radiolysis of monoclonal antibody during labeling. J. Nucl. Med. 1996, 37, 1384-1388.

27. Yatim, R.M.; Kannan, T.P.; Ab Hamid, S.S. Effect of gamma radiation on the expression of mRNA growth factors in glycerol cryopreserved human amniotic membrane. Cell Tissue Bank. 2016, 17, 643-651. [CrossRef]

28. Sershen; Berjak, P.; Pammenter, N.W.; Wesley-Smith, J. The effects of various parameters during processing for cryopreservation on the ultrastructure and viability of recalcitrant zygotic embryos of Amaryllis belladonna. Protoplasma 2012, 249, 155-169. [CrossRef]

29. Roopa, K.S.; Geetha, N.P.; Sharathchandra, R.G.; Pushpalatha, H.G.; Sudisha, J.; Amruthesh, K.N.; Prakash, H.S.; Shetty, H.S. Osmopriming enhances pearl millet growth and induces downy mildew disease resistance. Arch. Phytopathol. Plant Prot. 2009, 42, 979-987. [CrossRef]

30. Malik, S.; Ashraf, M. Exogenous application of ascorbic acid stimulates growth and photosynthesis of wheat (Triticum aestivum L.) under drought. Soil Environ. 2012, 31, 72-77.

31. Shah, T.; Latif, S.; Khan, H.; Munsif, F.; Nie, L. Ascorbic acid priming enhances seed germination and seedling growth of winter wheat under low temperature due to late sowing in Pakistan. Agronomy 2019, 9, 757. [CrossRef]

32. Farooq, M.; Barsa, S.M.A.; Wahid, A. Priming of field-sown rice seed enhances germination, seedling establishment, allometry and yield. Plant Growth Regul. 2006, 49, 285-294. [CrossRef]

33. Ahmad, I.; Basra, S.M.A.; Wahid, A. Exogenous application of ascorbic acid, salicylic acid and hydrogen peroxide improves the productivity of hybrid maize at low temperature stress. Int. J. Agric. Biol. 2014, 16, 825-830.

34. Luera, P.; Wahl-Villarreal, K.; Christoffersen, B.O.; Treviño, A.; Soti, P.; Gabler, C.A. Article effects of scarification, phytohormones, soil type, and warming on the germination and/or seedling performance of three tamaulipan thornscrub forest species. Plants 2021, 10, 1489. [CrossRef] [PubMed]

35. Komba, C.G.; Brunton, B.J.; Hampton, J.G. Accelerated ageing vigour testing of kale (Brassica oleracea L. var. acephala DC) seed. Seed Sci. Technol. 2006, 34, 205-208. [CrossRef]

36. TeKrony, D.M. Accelerated aging test: Principles and procedures. Seed Technol. 2005, 27, 135-146.

37. Winston, P.W.; Bates, D.H. Saturated solutions for the control of humidity in biological research. Ecology 1960, $41,232-237$. [CrossRef]

38. Ellis, R.H.; Roberts, E.H. Improved equations for the prediction of seed longevity. Ann. Bot. 1980, 45, 13-30. [CrossRef]

39. Bam, R.; Hong, T.; Ellis, R.; Kumaga, F.; Asiedu, E. Storage behaviour of two contrasting upland rice genotypes. Ghana J. Agric. Sci. 2008, 41, 113-120. [CrossRef]

40. Crawford, A.D.; Plummer, J.A.; Probert, R.J.; Steadman, K.J. The influence of cone age on the relative longevity of Banksia seeds. Ann. Bot. 2011, 107, 303-309. [CrossRef]

41. Patil, H.Y.; Mutanal, S.M.; Mokashi, M.V.; Ghatanatti, S.M. Germination and vigor index of different sources of Pongamia pinnata (L.) Pierre. Int. J. For. Crop Improv. 2017, 8, 8-11. [CrossRef]

42. Mahajan, G.; Sarlach, R.S.; Japinder, S.; Gill, M.S. Seed priming effects on germination, growth and yield of dry direct-seeded rice. J. Crop Improv. 2011, 25, 409-417. [CrossRef]

43. Patil, V.M.P.; Shivanna, H.; Surendra, P.; Manjunath, G.O.; Krishna, A.; Dasar, G. V Variability studies for seed and seedling traits in Pongamia pinnata (L.) Pierre. Karnataka J. Agric. Sci 2011, 24, 201-203.

44. Soltani, E.; Ghaderi-Far, F.; Baskin, C.C.; Baskin, J.M. Problems with using mean germination time to calculate rate of seed germination. Aust. J. Bot. 2015, 63, 631-635. [CrossRef]

45. Hussain, S.; Khaliq, A.; Matloob, A.; Wahid, M.A.; Afzal, I. Germination and growth response of three wheat cultivars to NaCl salinity. Soil Environ. 2013, 32, 36-43.

46. Jamil, M.; Rehman, S.; Rha, E.S. Salinity effect on plant growth, PSII photochemistry and chlorophyll content in sugar beet (Beta vulgaris L.) and cabbage (Brassica oleracea capitata L.). Pakistan J. Bot. 2007, 39, 753-760.

47. Abdul-Baki, A.A.; Anderson, J.D. Vigor determination in soybean seed by multiple criteria. Crop Sci. 1973, 13, 630-633. [CrossRef]

48. Kitajima, M.; Butler, W.L. Quenching of chlorophyll fluorescence and primary photochemistry in chloroplasts by dibromothymoquinone. Biochim. Biophys. Acta 1975, 376, 105-115. [CrossRef]

49. Sayed, O.H. Chlorophyll fluorescence as a tool in cereal crop research. Photosynthetica 2003, 41, 321-330. [CrossRef]

50. Moradi, F.; Ismail, A.M. Responses of photosynthesis, chlorophyll fluorescence and ROS-scavenging systems to salt stress during seedling and reproductive stages in rice. Ann. Bot. 2007, 99, 1161-1173. [CrossRef]

51. Probert, R.J.; Daws, M.I.; Hay, F.R. Ecological correlates of ex situ seed longevity: A comparative study on 195 species. Ann. Bot. 2009, 104, 57-69. [CrossRef] [PubMed]

52. Lee, H.-S.; Jeon, Y.-A.; Lee, Y.-Y.; Lee, S.-Y.; Kim, Y.-G. Comparison of seed viability among 42 species stored in a genebank. Korean J. Crop Sci. 2013, 58, 432-438. [CrossRef]

53. Xu, L.; Xin, X.; Yin, G.; Zhou, J.; Zhou, Y.; Lu, X. Timing for antioxidant-priming against rice seed ageing: Optimal only in non-resistant stage. Sci. Rep. 2020, 10, 13294. [CrossRef]

54. Ellis, R.H.; Nasehzadeh, M.; Hanson, J.; Woldemariam, Y. Medium-term seed storage of 50 genera of forage legumes and evidence-based genebank monitoring intervals. Genet. Resour. Crop Evol. 2018, 65, 607-623. [CrossRef]

55. Walters, C.; Fleming, M.B.; Hill, L.M.; Dorr, E.J.; Richards, C.M. Stress-response relationships related to ageing and death of orthodox seeds: A study comparing viability and RNA integrity in soya bean (Glycine max) cv. Williams 82. Seed Sci. Res. 2020, 30, 161-172. [CrossRef] 
56. Butler, L.H.; Hay, F.R.; Ellis, R.H.; Smith, R.D.; Murray, T.B. Priming and re-drying improve the survival of mature seeds of Digitalis purpurea during storage. Ann. Bot. 2009, 103, 1261-1270. [CrossRef]

57. Tang, S.; TeKrony, D.M.; Egli, D.B.; Cornelius, P.L.; Rucker, M. Survival characteristics of corn seed during storage: I. Normal distribution of seed survival. Crop Sci. 1999, 39, 1394-1400. [CrossRef]

58. Jatoi, S.A.; Afzal, M.; Nasim, S.; Anwar, R. Seed deterioration study in pea, using accelerated ageing techniques. Pakistan J. Biol. Sci. 2001, 4, 1490-1494. [CrossRef]

59. Walters, C.; Wheeler, L.M.; Grotenhuis, J.M. Longevity of seeds stored in a genebank: Species characteristics. Seed Sci. Res. 2005, 15, 1-20. [CrossRef]

60. Saxena, O.P.; Singh, G.; Pakeeraiah, T.; Pandey, N. Seed deterioration studies in some vegetable seeds. Acta Hortic. 1987, 215, 39-44. [CrossRef]

61. Kochanek, J.; Buckley, Y.M.; Probert, R.J.; Adkins, S.W.; Steadman, K.J. Pre-zygotic parental environment modulates seed longevity. Austral Ecol. 2010, 35, 837-848. [CrossRef]

62. Hay, F.; Klin, J.; Probert, R. Can a post-harvest ripening treatment extend the longevity of Rhododendron L. seeds? Sci. Hortic. 2006, 111, 80-83. [CrossRef]

63. Roberts, E.H.; Ellis, R.H. Water and seed survival. Ann. Bot. 1989, 63, 39. [CrossRef]

64. Walters, C. Understanding the mechanisms and kinetics of seed aging. Seed Sci. Res. 1998, 8, 223-244. [CrossRef]

65. Ellis, R.H.; Hong, T.D.; Roberts, E.H. Moisture content and the longevity of seeds of Phaseolus vulgaris. Ann. Bot. 1990, 66, 341-348. [CrossRef]

66. Copeland, L.O.; McDonald, M.B. Seed longevity and deterioration. In Principles of Seed Science and Technology; Springer: Boston, MA, USA, 1999; pp. 181-220.

67. Simon, E.W. Phospholipids and plant membrane permeability. New Phytol. 1974, 73, 377-420. [CrossRef]

68. Ellis, R.H.; Hong, T.D.; Roberts, E.H. Seed moisture content, storage, viability and vigour. Seed Sci. Res. 1991, 1, 275-279. [CrossRef]

69. Ellis, R.H.; Hong, T.D.; Roberts, E.H. Survival and vigour of lettuce (Lactuca sativa L.) and sunflower (Helianthus annuus L.) seeds stored at low and very-low moisture contents. Ann. Bot. 1995, 76, 521-534. [CrossRef]

70. Daws, M.I.; Lydall, E.; Chmielarz, P.; Leprince, O.; Matthews, S.; Thanos, C.A.; Pritchard, H.W. Developmental heat sum influences recalcitrant seed traits in Aesculus hippocastanum across Europe. New Phytol. 2004, 162, 157-166. [CrossRef]

71. Wang, Y.; Mu, C.; Hou, Y.; Li, X. Optimum harvest time of Vicia cracca in relation to high seed quality during pod development. Crop Sci. 2008, 48, 709-715. [CrossRef]

72. TeKrony, D.M. Precision is an essential component in seed vigour testing. Seed Sci. Technol. 2003, 31, 435-447. [CrossRef]

73. Farooq, M.; Basra, S.M.A.; Tabassum, R.; Afzal, I. Enhancing the performance of direct seeded fine rice by seed priming. Plant Prod. Sci. 2006, 9, 446-456. [CrossRef]

74. Ahmad, I.; Khaliq, T.; Ahmad, A.; Basra, S.M.A.; Hasnain, Z.; Ali, A. Effect of seed priming with ascorbic acid, salicylic acid and hydrogen peroxide on emergence, vigor and antioxidant activities of maize. African J. Biotechnol. 2012, 11, 1127-1132. [CrossRef]

75. Yousof, F.I.; Mersal, I.F.; El-Emam, A.A.M. Effect of soaking rice (Oryza sativa, L.) seed in some anitioxidants solutions on germination and seedling vigor under different salinity levels. J. Plant Prod. 2010, 1, 279-290. [CrossRef]

76. Brocklehurst, P.A.; Dearman, J. A comparison of different chemicals for osmotic treatment of vegetable seed. Ann. Appl. Biol. 1984, 105, 391-398. [CrossRef]

77. Dolatabadian, A.; Ali, S.; Modarres, M. Effect of the ascorbic acid, pyridoxine and hydrogen peroxide treatments on germination, catalase activity, protein and malondialdehyde content of three oil seeds. Not. Bot. Horti Agrobot. Cluj-Napoca 2008, 36, 61-66. [CrossRef]

78. Weraduwage, S.M.; Chen, J.; Anozie, F.C.; Morales, A.; Weise, S.E.; Sharkey, T.D. The relationship between leaf area growth and biomass accumulation in Arabidopsis thaliana. Front. Plant Sci. 2015, 6, 1-21. [CrossRef] [PubMed]

79. Gifford, R.M.; Thorne, J.H.; Hitz, W.D.; Giaquinta, R.T. Crop productivity and photoassimilate partitioning. Science (801-808). 1984, 225, 801-808. [CrossRef]

80. Koester, R.P.; Skoneczka, J.A.; Cary, T.R.; Diers, B.W.; Ainsworth, E.A. Historical gains in soybean (Glycine max Merr.) seed yield are driven by linear increases in light interception, energy conversion, and partitioning efficiencies. J. Exp. Bot. 2014, 65, 3311-3321. [CrossRef]

81. Vu, J.C.V.; Niedz, R.P.; Yelenosky, G. Glycerol stimulation of chlorophyll synthesis, embryogenesis, and carboxylation and sucrose metabolism enzymes in nucellar callus of "Hamlin" sweet orange. Plant Cell. Tissue Organ Cult. 1993, 33, 75-80. [CrossRef]

82. Ashraf, M.; Harris, P.J.C. Photosynthesis under stressful environments: An overview. Photosynthetica 2013, 51, 163-190. [CrossRef]

83. Xu, Y.-F.; Ookawa, T.; Ishihara, K. Analysis of the photosynthetic characteristics of the high-yielding rice cultivar Takanari. Japanese J. Crop Sci. 1997, 66, 616-623. [CrossRef]

84. Jarvis, A.J.; Davies, W.J. The coupled response of stomatal conductance to photosynthesis and transpiration. J. Exp. Bot. 1998, 49, 399-406. [CrossRef]

85. Miyashita, K.; Tanakamaru, S.; Maitani, T.; Kimura, K. Recovery responses of photosynthesis, transpiration, and stomatal conductance in kidney bean following drought stress. Environ. Exp. Bot. 2005, 53, 205-214. [CrossRef]

86. Hayat, S.; Yadav, S.; Wani, A.S.; Irfan, M.; Ahmad, A. Nitric oxide effects on photosynthetic rate, growth, and antioxidant activity in tomato. Int. J. Veg. Sci. 2011, 17, 333-348. [CrossRef] 
87. Kusumi, K.; Hirotsuka, S.; Kumamaru, T.; Iba, K. Increased leaf photosynthesis caused by elevated stomatal conductance in a rice mutant deficient in SLAC1, a guard cell anion channel protein. J. Exp. Bot. 2012, 63, 5635-5644. [CrossRef]

88. Gong, H.; Chen, K. The regulatory role of silicon on water relations, photosynthetic gas exchange, and carboxylation activities of wheat leaves in field drought conditions. Acta Physiol. Plant. 2012, 34, 1589-1594. [CrossRef]

89. Kumutha, D.; Ezhilmathi, K.; Sairam, R.K.; Srivastava, G.C.; Deshmukh, P.S.; Meena, R.C. Waterlogging induced oxidative stress and antioxidant activity in pigeonpea genotypes. Biol. Plant. 2009, 53, 75-84. [CrossRef]

90. Miyake, C.; Asada, K. Thylakoid-bound ascorbate peroxidase in spinach chloroplasts and photoreduction of its primary oxidation product monodehydroascorbate radicals in thylakoids. Plant Cell Physiol. 1992, 33, 541-553. [CrossRef]

91. Zhang, S.; Weng, J.; Pan, J.; Tu, T.; Yao, S.; Xu, C. Study on the photo-generation of superoxide radicals in Photosystem II with EPR spin trapping techniques. Photosynth. Res. 2003, 75, 41-48. [CrossRef] [PubMed]

92. Dolatabadian, A.; Modarres Sanavy, S.A.M.; Sharifi, M. Alleviation of water deficit stress effects by foliar application of ascorbic acid on Zea mays L. J. Agron. Crop Sci. 2009, 195, 347-355. [CrossRef]

93. Zhao, H.J.; Zou, Q. Protective Effects of exogenous antioxidants and phenolic compounds on photosynthesis of wheat leaves under high irradiance and oxidative stress. Photosynthetica 2002, 40, 523-527. [CrossRef]

94. Foyer, C.H.; Noctor, G. Redox sensing and signalling associated with reactive oxygen in chloroplasts, peroxisomes and mitochondria. Physiol. Plant. 2003, 119, 355-364. [CrossRef]

95. Foyer, C.H.; Shigeoka, S. Understanding oxidative stress and antioxidant functions to enhance photosynthesis. Plant Physiol. 2011, 155, 93-100. [CrossRef] [PubMed] 